\title{
Pre-service Teachers' Humanistic vs. Custodial Beliefs: Before and After the Student Teaching Experience
}

\author{
Megan Schramm-Possinger \\ Correspondence: Megan Schramm-Possinger, University of North Florida, College of Education and Human Services, \\ Jacksonville, Florida, USA
}

Received: September 10, 2015

Accepted: September 28, $2015 \quad$ Online Published: October 9, 2015

doi:10.11114/jets.v4i1.1080

URL: http://dx.doi.org/10.11114/jets.v4i1.1080

\begin{abstract}
The student teaching experience is cited as one of the most critical facets of teachers' professional development. However, teachers' beliefs about pedagogical practices and disciplinary procedures, as well as their perceptions of students, also influence the approaches they use in the classroom. This study uses a humanistic and custodial orientation theoretical framework to compare the beliefs of pre-service teachers immediately after having completed their core didactic coursework - but prior to the student teaching experience - with their beliefs immediately after the student teaching experience. Findings from this study reveal that upon completion of their didactic coursework, pre-service-teachers' espouse humanistic beliefs, in contrast to a custodial orientation. Furthermore, although the use of external rewards to shape student behavior as well as other specific management and pedagogical practices were more highly prioritized after immersion in the field, student teaching did not appear to alter pre-service teachers' core beliefs.
\end{abstract}

Keywords: teacher training, student teaching, teacher beliefs, humanistic and custodial orientations

\section{Theoretical Background}

\subsection{Introduction}

Student teaching is pre-service teachers "first 'real' teaching assignment," and as such is considered to be "the most important experience in the professional preparation of teachers" (Sanderson, 2003, p. 1). Perhaps not surprisingly, The Council for the Accreditation of Educator Preparation (CAEP) recently mandated that teacher preparation programs must "ensure that effective partnerships and high quality clinical practice are central to [teacher] preparation so that candidates develop the knowledge, skills and dispositions necessary to demonstrate positive impact on all P-12 students' learning" (Council for the Accreditation of Educator Preparation [CAEP, 2013]; Grossman, 2010). This standard is consistent with research on the salience of providing pre-service teachers with quality student teaching internships that are grounded in theories of learning and teaching (Darling-Hammond \& Baratz-Snowden, 1995; Holmes Group, 1995; Conant, 1963).

Student teaching experiences also offer opportunities for pre-service teachers to embed their theoretical schemas into a knowledge of practice by gradually assuming the professional role for which they are preparing (Brimfield \& Leonard, 1983). For example, many pre-service teachers, who may have been taught as K-12 learners through lecture and other "traditional means," come to understand the efficacy of non-traditional pedagogical approaches such as Problem-Based Learning (PBL) during their teacher training (Blumenfeld, Soloway, Marx, Krajcik, Guzdial, \& Palinscar, 1991). The gap between pre-service teachers' past experiences as students and their newly cultivated beliefs about practice (in this case, PBL) can, potentially, be closed if they are successfully able to plan, execute, and evaluate a problem-based learning lesson (Eisenhardt, Besnoy, \& Steele, 2012; Capraro, M.M., Capraro, R. M, \& Helfeldt, 2010). Furthermore, whether or not pre-service teachers utilize the pedagogical approaches they are taught - such as PBL - depends more upon whether they truly believe in the value of problem based learning and less upon their knowledge of the approach, rendering beliefs as well as experience to be powerful drivers of what teachers know and do (Eisenhardt et al., 2012; Anderson \& Holt-Reynolds, 1995). In short, the quality of belief change reflects, in part, the degree to which pre-service teachers' have woven theories of learning and teaching into a realistic and workable framework of practice.

However, instead of using more progressive, humanistic theories of best practice student teachers are likely to have learned of in their teacher preparation programs, in some instances they will revert back to teaching the way they were taught and use more conventional, teacher-directed pedagogical approaches (Tabachnick \& Zeichner, 1984; Bagher 
Shabani, 2013; Zeichner, K.M., \& Tabachnick, B.R., 1981). For example, Anderson and Holt-Reynolds (1995) report that prospective teachers who are inexperienced in classifying student difficulties - such as disinterest in completing a reading exercise - may attribute this to their personal past experiences such as a lack of interest, instead of implementing strategies they were taught to support struggling readers. This is a function of the reciprocal relation between beliefs and behavior, with beliefs compelling actions, experiences and perceptions of these actions changing beliefs, and so on and so forth (Richardson, 1996; Fang, 1996; Pajares, 1992). Justifications for outcomes can also be informed by beliefs, and these perceptions can influence whether specific forms of information are attended to, dismissed as erroneous, or ignored entirely (Calderhead \& Robson, 1991; Doolittle, Dodds \& Palcek). Thus, beliefs mold that which is learned by student teachers, making the study of teachers' beliefs the first step if teacher educators are to facilitate ways for them to reframe and be willing to learn differing pedagogical practices (Anderson, Holt-Reynolds, 1995; Karavas \& Drossou, 2010).

\subsection{Teacher Beliefs}

\subsubsection{Teacher Belief Change}

Understanding whether student teachers' beliefs change, and in what ways, is therefore of great importance in determining whether the conventional teacher training program - i.e., coursework with some field experiences followed by a culminating student teaching experience -- facilitates pre-service teachers' reconciliations between theories of best teaching and the complexities of practice (Edwards-Groves, 2014; Haymore Sandholtz, 2011; Nespor, J., 1987; Oh, Ankers, Llamas, \& Tomyoy, 2005; Ball, 1990; Moore \& Leonard, 1990). Such an understanding also is important because it informs subsequent teaching and professional development efforts that can either draw upon the beliefs new teachers espouse and/or challenge their beliefs in ways that are likely to foster continued professional growth.

To inform our understanding on this topic, this study compares the beliefs held by pre-service teachers immediately after having completed their core didactic coursework - but prior to participating in student teaching - with those held immediately after the student teaching experience. To set the stage for the study, I begin with the nature of teacher beliefs and why studying them is important. This is followed by a brief overview of the student teaching experience, as well as prior scholarship on the effects of this learning experience on belief change.

\subsubsection{Teacher Beliefs Influence Practice}

Teacher beliefs tend to be strongly aligned with teacher practices (Lombaerts, De Backer, Engels, van Braak \& Athanasou, 2009). Research on teacher training indicates the lasting effects derived from the student teaching experience - and field practices in general -- on new teachers' beliefs and future pedagogical approaches (Nilssen \& Solheim, 2015). For example, when required to teach different subjects at different grade levels, teachers frequently retained the core pedagogical priorities that they developed early in their training (Lombaerts et al., 2009). School culture, characteristics, and practices either compel student teachers to espouse views that are consistent with them, or to do the opposite. Beliefs are of paramount importance, as "teachers' beliefs lie at the very heart of teaching" (Buehl \& Fives, 2009, p. 367).

\subsubsection{Custodial versus Humanistic Beliefs}

Teacher beliefs have been operationalized in many ways, but are most often defined in terms of what teachers implicitly assume to be true of students, classroom environments, course content, and the process of learning in general (Kagan, 1992). To examine these assumptions and how they change over time, it is important to categorize individual beliefs and perceptions according to one or more overall philosophies. Framing beliefs along a continuum ranging from a custodial orientation to that which is humanistic serves this purpose. On the teacher- directed end of the spectrum is a custodial orientation. The second, on the progressive end of the spectrum of teacher beliefs is a humanistic orientation. Presumably teacher beliefs and their corresponding practices fall somewhere along the spectrum between custodial and humanistic orientations, with philosophies for some educators falling on the extreme ends (Hoy, 1967; Hoy, 1968; Hoy \& Woolfolk, 1990).

In general, educators who endorse a custodial classroom management and pedagogical approach believe that students cannot be trusted to direct their learning, thus necessitating the use of top-down, teacher-directed control. One consequence of this approach is that differentiation of instruction according to students' personalities and strengths, as well as fostering their self-regulatory capabilities, is discouraged. Teachers who believe in this dogma tend not to tolerate being challenged by students, as well. Conversely, in general, educators who espouse a humanistic pedagogical orientation highly value creating a classroom community and wish to foster students' self- discipline. Reciprocal communication from students to their teachers and vice versa is embraced, as well (Hoy, 1967; Hoy, 1968; Hoy \& Woolfolk, 1990).

\subsubsection{Formation of Teacher Beliefs}

In thinking about the potential role of the student teaching experience on teachers' beliefs, it is helpful to understand how such beliefs are formed in the first place. Implicit episodic memories develop throughout one's lifespan and influence 
both beliefs and behaviors. Among teachers, these memories necessarily include events experienced as both a student and a professional (Raths, 2000). Some episodes, as well as other forms of implicit long-term memories, have been repeatedly reinforced and are thus less subject to change than others. In addition, beliefs based on episodes are unbounded and therefore less malleable in the face of reason, such as considerations of best pedagogical practice (Thomas, Pederson \& Finson, 2001). Other beliefs, however, are more peripheral and can be altered, particularly when challenged by respected authorities such as educational experts (Ertmer, 2005).

Consequently, even the theoretical tenets of "best pedagogical practice" explicitly taught to pre-service teachers in numerous schools of higher education can - and are - sometimes trumped by models of teaching internalized earlier during the pre-service teacher's own experience as an elementary or high school student. For example, educators who were taught inquiry-based pedagogical techniques were found to "tack-on" those practices to their pre-existing, traditional beliefs, rather than make fundamental changes to those beliefs (Stipek, Givvin, Salmon \& Mac Gyvers, 2001).

As alluded to previously, there are instances, however, when teachers have espoused one consistent set of beliefs, but after explicit training, subsequently endorsed another set of beliefs. For example, pre-service teachers who were explicitly taught Developmentally Appropriate Practices were more adept at scaffolding their students' learning in contrast with their peers in a control group, who were not disabused of their Developmentally Inappropriate Practices, thus demonstrating the value of this intervention (Abu-Jaber, Al-Shawareb \& Gheith, 2010; Cassidy, Buell, Pugh-Hoese, Russell, 1995).

Tacit beliefs can also draw teachers closer to "trying out" novel or unconventional practices that their colleagues may not embrace. For instance, Windschitl and Sahl (2002) reported a case of a teacher, dissatisfied with traditional pedagogical approaches, who was taught how to effectively use technology in her teaching. Upon completion of this training, she frequently utilized technology when teaching and also facilitated student learning through the use of constructivist techniques. Perhaps not surprisingly, teachers who were provided with the same training on the effective use of technology and constructivist pedagogical practices, but were not dissatisfied with using traditional teaching techniques, retained their traditional teaching approaches. They also did not utilize the new knowledge and technological tools they had recently learned. This example reveals the way in which beliefs serve as a filter through which knowledge is integrated and applied, and also suggests that knowledge can reciprocally expand ideas and replace practices and dogma from the past (Windschitl \& Sahl, 2002).

\subsubsection{The Student Teaching Experience and Teacher Beliefs}

Teacher certification programs typically require pre-service teachers to participate in a culminating student teaching internship. The immersive level of participation in the student teaching internship differs from the field experience, as the latter requires pre-service teachers to act in a more peripheral capacity, such as conducting observations, engaging in action research, tutoring students, or assisting the teacher. In student teaching experiences, pre-service teachers may begin by simply "observing how specific teaching behaviors and teaching strategies are managed as well as gaining familiarity with the students, curriculum, and partner school," but by the end of the student teaching internship, be responsible for teaching every class, grading all of the students and/or even organizing a field trip" (University of North Florida Internship Handbook, 2014, p. 21).

A significant research base explores the relationship between student teaching, pre-service teaching coursework and teacher beliefs. These data indicate that pre-service teachers" "lay-theories" color their perceptions of what they learn in their didactic coursework, which is further shaped -- in enduring ways -- during their student teaching experience (Anderson, Holt-Reynolds, 1995). Such skills and practices include diversification of lessons to meet student needs, re-teaching, classroom management, record keeping, organization, procedural efficiency, and communication with parents (Spooner, Flowers, Lambert \& Algozzine, 2008).

Prior research has focused on teacher belief change during the student teaching experience. For example, Wooley, Wolley, \& Hosey (1999) reported that student teachers' beliefs in the benefits of constructivist pedagogical practices and behaviorism were strengthened after having watched their cooperating teacher use such approaches, and after having received support to try out these techniques as student teachers. This finding was substantiated by Erdogan (2015) who asserted that, as per their scores on a constructivist scale, student teachers' constructivist beliefs were stronger after having student taught. Additional theorists documented similar results (Lin, Hazareesingh, Taylor, Gorrell \& Carlson, 2001; Nettle, 1998; Wooley et al., 1999). Teachers newly acquired beliefs regarding the efficacy of using constructivist pedagogical approaches has also resulted in positive student outcomes, illustrating the way educators' beliefs and attendant practices mediate student growth (Mischo \& Maaß, 2013).

Alternatively, other studies indicated that the "real life" stressors pre-service student teachers and novice teachers faced led them to espouse more controlling, authoritarian, and custodial beliefs. This may have been a function of pre-service teachers' interest in minimizing classroom disruption as opposed to focusing on the use of pedagogical techniques that 
facilitate student learning (Rozelle \& Wilson, 2012; Kagan, 1992; Hoy and Woolfolk, 1990).

Additional research has shown that institutional norms influence belief change as well (Tabachnick \& Zeichner, 1984). For example, Smith (1997) studied the influence of cooperating teachers and bureaucratic mandates on student teachers' beliefs and found that both variables shaped which pedagogical practices they considered to be effectual and salient.

Beliefs about what "good teachers" prioritize are partially shaped by knowledge; however, these propositions are intermingled with and colored by episodic and affective information derived from experience (Pajares, 1992; Borg, 2001; Parker \& Brindley, 2008; Fang, 1996; Kagan, 1992; Mayer, 2006; Zeichener \& Tabachnick, 1981; \& Lortie, 1975).

\subsubsection{Importance of Using the TBQ to Assess Preservice Teachers' Beliefs before and After Having Student Taught}

It is important to note that the methodology for previous studies on preservice/novice teachers' beliefs prior to and after their teaching apprenticeships tends to rely on case studies, interviews or self-report surveys on a Likert-Scale. Of course, case studies, such as those conducted by King, Shumow, \& Lietz (2001) often yield rich sources of data, but the results derived from them may or may not reflect the larger population. For example, Mayer (2006) reported that despite the challenges a student teacher faced when trying to use primary documents with her class - such as students' inability to understand the text, her personal time constraints, and the students' consistent wish to be granted a quick answer - she persevered and taught history in a manner consistent with her belief system and, as such, neither the integrity of her beliefs nor her attendant practices was altered by classroom challenges confronted in the "real world." Self-report surveys are limited as well due to response bias, as respondents tend to rate themselves in ways that present them favorably (Rimm-Kaufman, Storm, Sawyer, Pianta, \& LaParo, 2006). The majority of measures used to determine teachers' beliefs are surveys comprised of Likert-scale questions (Parker \& Brindley, 2008; File \& Gullo, 2002; Solomon \& Battistich, 1996; Glickman \& Tamashiro, 1982). Specifically, the Teaching Style Survey (Grasha \& Riechmann, 1996) reveals whether the participant's teaching orientation is that of an expert, formal authority, personal model, facilitator or delegator. In addition, The Teaching Goals Inventory (Angelo \& Cross, 1993) reveals the degree of agreement in response to a list of 52 goals, and The Instructor Beliefs Self-Assessment (McCombs \& Whisler, 1997), are additional measures that assess categories of teachers' beliefs.

Finally, the survey used to assess the degree to which participants believe in using either transmissive (akin to custodial) or progressive (akin to humanistic) pedagogical approaches is called the Witcher-Travers Survey of Educational Beliefs (WTSEB) (Witcher \& Travers, 1999).

La Paro, Siepak \& Scott-Little (2009) have used the TBQ to evaluate 25-30 early childhood preservice teachers' beliefs at three time points: (1) the introduction of their teacher training; (2) soon before their student teaching experience; and, (3) upon completion of their student teaching experience. Eight faculty members' beliefs were also assessed. Their results indicate that preservice teachers' beliefs about children remained relatively stable from the beginning to the end of their program; additionally, participants' beliefs about children were similar to faculty members' beliefs. Beliefs about teaching practices, discipline and behavior management, however, changed among preservice teachers over time. Specifically, preservice teachers' beliefs regarding discipline, behavior management and teaching practices, both before and after their student teaching, differed from their prior prioritizations (at the start of their teacher education), with their beliefs at the student teaching phase of their training more closely aligned with the beliefs of education faculty members (La Paro et al., 2009). Results of this study indicate illustrate the benefits of using q-sort methodology to capture preservice teachers' beliefs, as well as how/whether their beliefs change, throughout their professional training.

This study addresses constraints associated with using traditional surveys and inventories through the use of the TBQ: a measure that required student teachers to rank their beliefs in relation to other beliefs, so that the priorities driving their practices are revealed. In addition, -- as compared to the study described above -- this study includes a larger number of student teachers $(\mathrm{n}=95)$ who completed the TBQ at both time one and time two, potentially making it more likely for these results to be generalizable to the K-12 teacher training populations. The methodology for the study is described next.

\section{Method}

\subsection{Participant Characteristics}

This study used a sample of 95 pre-service teachers enrolled in the final year of a five-year, Master's level teacher preparation in a northeastern university. Sixty-eight percent of the sample participants were female and 32 percent of the sample were male; the mean age of participants, as an aggregate, was 23 . Their specific certification tracks included elementary education (grades K-6), subject-specific middle school education (grades 6-8), secondary education (grades 9-12), and K-12 special education; $38 \%$ of participants were preparing to teach subject-specific middle school or secondary education, $21 \%$ were preparing to teach special education, $41 \%$ were preparing to teach elementary education. All students in this teacher preparation program are assigned to student teach in an urban or suburban schools. Their 
student teaching is viewed to be a culminating experience, and thus completed during their second-to-last semester prior to graduation. As a result, many (if not most) of these pre-service teachers have limited exposure to K-12 students prior to their student teaching, also making this culminating experience their first substantive opportunity to reconcile theory with practice.

\subsection{Sampling Procedures}

Upon receipt of IRB approval, the sample was recruited while enrolled in either "Assessment or Measurement for Teachers" or its counterpart "Assessment and Measurement for Special Education Teachers." Both classes are the last class pre-service teachers take before embarking on their student teaching. During the first or second meeting of the class, participants were provided with a description of the study, including the instructions for online participation, the amount of time required to complete the measure, the possible benefits that may or may not be derived as a result of having participated, and a consent form. Upon initially consenting, the sample was asked to participate in data collection within two weeks. Then, one month after the conclusion of their student teaching experiences - and while enrolled in their final semester before graduation - the same participants were asked to participate again.

\subsection{Measure}

To collect data on the beliefs of this sample of pre-service teachers, the study used the Teacher Belief Q-Sort (TBQ; Rimm-Kaufman et al., 2006). The TBQ is an online method for assessing teacher priorities and beliefs by requiring participants to rank their beliefs in relation to other beliefs, so that the priorities driving their practices are revealed. Beliefs are categorized under three domains: discipline and behavior management, pedagogical practices, and beliefs about children. For the first category, the spectrum of priorities range from behaviorist techniques, such as shaping and response cost, to managing the classroom through relationship cultivation and other humanistic means. The second category, pedagogical practices, ranges from those espoused by information processing theorists, where techniques such as confirming feedback, facilitating student thought, and fostering metacognition are extensively discussed and endorsed, to the salience of belonging and social cohesion as fundamental for learning. Finally, beliefs about children include the degree to which children are naturally driven to learn, as well as whether or not children learn through teacher-driven lectures or more student- directed activities. A copy of the sixty items in the measure is included in the Appendix.

Completing the TBQ requires participants to sort their beliefs by dragging four statement cards to five categories ranging between values of four and zero. If participants drag any number other than the required four statement cards for each of the five categories, then they are not able to proceed to the next screen to complete the measure. A value of "four" represents a statement card which is of the "highest priority," a "three" represents a statement card which is a "priority," "two" represents a statement card which is prioritized as "neutral," and scores in the "one" and "zero" range represent the lowest prioritization of a statement card.

In addition to having psychometric indices which support the validity and reliability of the TBQ, its reliability was established by asking 44 teachers to take the measure twice within one year (Rimm-Kaufman et al., 2006). The correlation between each participant's scores across the individual items ranged from 50 to .90 with a relatively low standard deviation of .11 and a mean of .71. These strong, positive correlations indicate that the TBQ is a reliable instrument.

The TBQ also has been used to assess the beliefs of four groups of teachers with respect to classroom management, perceptions of students and preferred pedagogical practices, as well as whether their beliefs changed after having been trained in the Responsive Classroom Approach (RC). Results revealed that pre-service educators did not highly prioritize students' general likability and personal motivation but did demonstrate a higher prioritization of collaboration and spontaneity in comparison to their more experienced counterparts. In addition, after having been trained in RC pedagogical strategies participants prioritization of students 'being known' increased, illustrating the effects of RC training on teachers' belief change (Rimm-Kaufman, Storm, Sawyer, Pianta, \& LaParo, 2006).

\subsection{Analysis Strategies}

A three-pronged approach was used to analyze the TBQ data and address the study's research questions. First, because the degree to which participants espoused a humanistic or custodial approach at the two time points was of particular interest, the TBQ items were classified as humanistic (H), custodial (C) or N/A for not applicable. These designations, based upon the face validity of the statements, are displayed in Table 1.

Next, to determine student-teachers' beliefs at pre- and post-student teaching, descriptive statistics of participants' prioritizations were computed for each of the $60 \mathrm{TBQ}$ statement cards, with statements then rank ordered from the highest mean prioritization to the lowest, before and after student teaching.

Finally, to address whether certain beliefs changed in prioritization for preservice teachers after having student taught, changes in rankings for specific beliefs from the low, medium and highest ends of the scale were identified. 


\section{Results}

\subsection{Pre-service Teachers' Beliefs Prior to Student Teaching}

\subsubsection{Highly Prioritized Beliefs Prior to Student Teaching}

The first research question concerns pre-service teachers' beliefs at the close of their didactic coursework and prior to student teaching. Analysis of the most highly prioritized statements shows these statements reflect a humanistic orientation (Table 1). For example, of high priority to these participants were:

- "Students should feel as though they are 'known' and 'recognized' in the classroom";

- "Students need to feel safe and secure in the classroom";

- "If I treat students with respect, kindness and concern, there are less [sic] behavior problems";

- "Doing an activity to create a sense of community";

- "Students meet challenges best when they feel their teachers care about them"; and

- "It is important to respect students' autonomy and expect them to act in a responsible manner."

Table 1. TBQ Statement Cards by Mean Rank

TBQ Statement Card Categories:

$\mathrm{C}=$ Beliefs About Classroom Management

$\mathrm{T}=$ Beliefs about Teaching

$\mathrm{S}=$ Beliefs about Students

Number=Statement Card Number

17 T. Encouraging students and giving feedback that focuses on the process of students' creations or thinking, not the outcomes of the solution

$3 \mathrm{~S}$. Students should feel as though they are 'known' and

'recognized' in the classroom

9 C. A classroom runs smoothly when there are clear expectations for behavior

$14 \mathrm{~S}$. Students need to feel safe and secure in the classroom

$4 \mathrm{C}$. When students are engaged in interesting problems and challenging activities, they tend to have very few discipline problems $17 \mathrm{~S}$. Students learn best by being actively involved in lessons

$4 \mathrm{~T}$. Doing an activity to create a sense of community

11. C Self-monitoring (or self-regulation) are important skills for students to develop

$17 \mathrm{C}$. If I treat students with respect, kindness, and concern, there are less behavior problems

$11 \mathrm{~T}$. Reflecting on the content of an academic lesson and talking about what we learned

10 C. Classroom rules should be discussed and posted

$18 \mathrm{~S}$. Students need opportunities to be creative in the classroom

$16 \mathrm{~S}$. Students need to have their strengths recognized to promote learning

13 T. Modeling behavior for students

$13 \mathrm{~S}$. Students meet challenges best when they feel their teachers care about them

12 C. It is important to respect students' autonomy and expect them to act in a responsible manner

$4 \mathrm{~S}$. Students need to be met where they are in terms of their ability

9 S. Students learn best when they have good role models for behavior

\begin{tabular}{|c|c|c|c|c|}
\hline \multicolumn{3}{|c|}{$\begin{array}{l}\text { Orientation Type: } \\
\text { H=Humanistic, } \\
\mathrm{C}=\text { Custodial, } \\
\text { N/A=Not } \\
\text { Applicable }\end{array}$} & \multirow{2}{*}{$\begin{array}{l}\text { Pre- } \\
\text { student } \\
\text { teaching } \\
\text { internship } \\
\text { Mean } \\
\text { (Standard } \\
\text { Deviation) }\end{array}$} & \multirow{2}{*}{$\begin{array}{l}\text { Post- } \\
\text { student } \\
\text { teaching } \\
\text { internship } \\
\text { Mean } \\
\text { (Standard } \\
\text { Deviation) }\end{array}$} \\
\hline Type & $\begin{array}{l}\text { Rank } \\
\text { T1 }\end{array}$ & $\begin{array}{l}\text { Rank } \\
\text { T2 }\end{array}$ & & \\
\hline $\mathrm{H}$ & 1 & 2 & $\begin{array}{l}3.29 \\
(1.051)\end{array}$ & $\begin{array}{l}3.34 \\
(1.006)\end{array}$ \\
\hline $\mathrm{H}$ & 2 & 4 & $\begin{array}{l}3.27 \\
(1.044)\end{array}$ & $\begin{array}{l}3.16 \\
.770\end{array}$ \\
\hline N/A & 3 & 1 & $\begin{array}{l}3.23 \\
(.928)\end{array}$ & $\begin{array}{l}3.49 \\
(.797)\end{array}$ \\
\hline $\mathrm{H}$ & 4 & 3 & $\begin{array}{l}3.22 \\
(.931)\end{array}$ & $\begin{array}{l}3.24 \\
(1.097)\end{array}$ \\
\hline N/A & 5 & 5 & $\begin{array}{l}3.20 \\
(.963)\end{array}$ & $\begin{array}{l}3.13 \\
(1.104)\end{array}$ \\
\hline N/A & 6 & 7 & $\begin{array}{l}3.08 \\
(1.135)\end{array}$ & $\begin{array}{l}3.04 \\
(1.151)\end{array}$ \\
\hline $\mathrm{H}$ & 7 & 6 & $\begin{array}{l}3.04 \\
(.978)\end{array}$ & $\begin{array}{l}3.05 \\
(1.014)\end{array}$ \\
\hline $\mathrm{H}$ & 8 & 18 & $\begin{array}{l}2.98 \\
(1.091)\end{array}$ & $\begin{array}{l}2.62 \\
(1.231)\end{array}$ \\
\hline $\mathrm{H}$ & 9 & 16 & $\begin{array}{l}2.96 \\
(1.051)\end{array}$ & $\begin{array}{l}2.75 \\
(1.203)\end{array}$ \\
\hline N/A & 10 & 8 & $\begin{array}{l}2.95 \\
(1.308)\end{array}$ & $\begin{array}{l}3.04 \\
(1.184)\end{array}$ \\
\hline N/A & 11 & 10 & $\begin{array}{l}2.93 \\
(1.064)\end{array}$ & $\begin{array}{l}2.86 \\
(1.126)\end{array}$ \\
\hline $\mathrm{H}$ & 12 & 14 & $\begin{array}{l}2.77 \\
(1.171)\end{array}$ & $\begin{array}{l}2.78 \\
(.976)\end{array}$ \\
\hline $\mathrm{H}$ & 13 & 13 & $\begin{array}{l}2.75 \\
(1.090)\end{array}$ & $\begin{array}{l}2.81 \\
(.936)\end{array}$ \\
\hline N/A & 14 & 9 & $\begin{array}{l}2.75 \\
(1.101)\end{array}$ & $\begin{array}{l}2.94 \\
(.987)\end{array}$ \\
\hline $\mathrm{H}$ & 15 & 11 & $\begin{array}{l}2.72 \\
(1.280)\end{array}$ & $\begin{array}{l}2.82 \\
(1.021)\end{array}$ \\
\hline $\mathrm{H}$ & 16 & 22 & $\begin{array}{l}2.66 \\
(1.208)\end{array}$ & $\begin{array}{l}2.54 \\
(1.262)\end{array}$ \\
\hline N/A & 17 & 12 & $\begin{array}{l}2.59 \\
(1.163)\end{array}$ & $\begin{array}{l}2.81 \\
(1.191)\end{array}$ \\
\hline N/A & 18 & 15 & $\begin{array}{l}2.59 \\
(.992)\end{array}$ & $\begin{array}{l}2.76 \\
(1.026)\end{array}$ \\
\hline
\end{tabular}


14 C. Rules for the students' classroom need to be reinforced consistently

16 T. Permitting students to choose from a

variety of activities

$10 \mathrm{~T}$. Reflecting and talking about something such as a social

interaction that worked or didn't work in our class

$1 \mathrm{~T}$. Having a morning routine

$5 \mathrm{~S}$. Each of my students teaches me something

19 C. If I anticipate problems before they happen and discuss them with the students, I have fewer discipline problems

$3 \mathrm{~T}$. Welcoming each student by name to class

$1 \mathrm{~S}$. Almost all children in my class try their best

$10 \mathrm{~S}$. Students need some choice of activities in the classroom

2C. A noisy classroom is okay as long as all the students are being productive

$14 \mathrm{~T}$. Introducing new objects or new activities through

demonstration

$20 \mathrm{~T}$. Working on group projects

$5 \mathrm{~T}$. Talking about current events

$2 \mathrm{~T}$. Talking about our plan or schedule for the day

7 T. Having at least a few students share something that has happened to them

$6 \mathrm{C}$. Monitoring students can prevent problematic situations

5 C. Proper control of a class is apparent when students work productively when I am out of the room

15 C. Praise from me is an effective way to change students'

behavior

19 P. Using a theme-based approach to instruction

$1 \mathrm{C}$. The primary goal in dealing with students' behavior is to establish and maintain control

$7 \mathrm{~S}$. Most students respect teachers authority

$18 \mathrm{~T}$. Using whole group instruction

$9 \mathrm{~T}$. Conducting the business of the classroom (e.g., collecting lunch or milk money)

$13 \mathrm{C}$. Students should try to resolve conflicts on their own before going to the teacher

$12 \mathrm{~S}$. Students cannot be understood without knowing something about their families

$15 \mathrm{~S}$. Students need opportunities to think in a quiet classroom environment

$18 \mathrm{C}$. Verbal punishment is an unacceptable means of controlling

students' behavior; I believe it's more important to use only positive management techniques

$8 \mathrm{C}$. The curriculum and class schedule need

to be prioritized over specific student interests

$6 \mathrm{~S}$. Almost all students are equally likable and enjoyable

$11 \mathrm{~S}$. Students need to work on skills at which they are not good, even if it means giving them fewer choices of activities

$8 \mathrm{~T}$. Discussing a written announcement or message created by the teacher

3 C. Students must be kept busy doing activities or they soon get into trouble

20 C. Extrinsic rewards

for desirable behavior (e.g., stickers, candy bars, undermine student's motivation

\begin{tabular}{|c|c|c|c|c|}
\hline N/A & 19 & 17 & $\begin{array}{l}2.45 \\
(1.236)\end{array}$ & $\begin{array}{l}2.69 \\
(1.131)\end{array}$ \\
\hline N/A & 20 & 28 & $\begin{array}{l}2.37 \\
(1.158)\end{array}$ & $\begin{array}{l}2.32 \\
(1.142)\end{array}$ \\
\hline N/A & 21 & 20 & $\begin{array}{l}2.36 \\
(1.296)\end{array}$ & $\begin{array}{l}2.56 \\
(1.327)\end{array}$ \\
\hline N/A & 22 & 26 & $\begin{array}{l}2.35 \\
(1.351)\end{array}$ & $\begin{array}{l}2.45 \\
(1.261)\end{array}$ \\
\hline $\mathrm{H}$ & 23 & 25 & $\begin{array}{l}2.33 \\
(1.219)\end{array}$ & $\begin{array}{l}2.48 \\
(1.274)\end{array}$ \\
\hline N/A & 24 & 30 & $\begin{array}{l}2.32 \\
(1.323)\end{array}$ & $\begin{array}{l}2.23 \\
(1.180)\end{array}$ \\
\hline $\mathrm{H}$ & 25 & 24 & $\begin{array}{l}2.31 \\
(1.305)\end{array}$ & $\begin{array}{l}2.49 \\
(1.100)\end{array}$ \\
\hline $\mathrm{H}$ & 26 & 31 & $\begin{array}{l}2.27 \\
(1.376)\end{array}$ & $\begin{array}{l}2.11 \\
(1.306)\end{array}$ \\
\hline N/A & 27 & 19 & $\begin{array}{l}2.26 \\
(1.083)\end{array}$ & $\begin{array}{l}2.61 \\
(1.053)\end{array}$ \\
\hline $\mathrm{H}$ & 28 & 23 & $\begin{array}{l}2.24 \\
(1.286)\end{array}$ & $\begin{array}{l}2.53 \\
(1.090)\end{array}$ \\
\hline N/A & 29 & 27 & $\begin{array}{l}2.23 \\
(1.153)\end{array}$ & $\begin{array}{l}2.33 \\
(1.233)\end{array}$ \\
\hline N/A & 30 & 21 & $\begin{array}{l}2.22 \\
(1.239)\end{array}$ & $\begin{array}{l}2.56 \\
(1.182)\end{array}$ \\
\hline N/A & 31 & 36 & $\begin{array}{l}2.16 \\
(1.170)\end{array}$ & $\begin{array}{l}1.89 \\
(1.086)\end{array}$ \\
\hline N/A & 32 & 34 & $\begin{array}{l}2.14 \\
(1.245)\end{array}$ & $\begin{array}{l}1.95 \\
(1.304)\end{array}$ \\
\hline $\mathrm{H}$ & 33 & 33 & $\begin{array}{l}2.09 \\
(1.112)\end{array}$ & $\begin{array}{l}1.96 \\
(1.166)\end{array}$ \\
\hline N/A & 34 & 32 & $\begin{array}{l}1.96 \\
(1.271)\end{array}$ & $\begin{array}{l}2.03 \\
(1.056)\end{array}$ \\
\hline N/A & 35 & 35 & $\begin{array}{l}1.95 \\
(1.258)\end{array}$ & $\begin{array}{l}1.93 \\
(1.169)\end{array}$ \\
\hline N/A & 36 & 29 & $\begin{array}{l}1.95 \\
(1.232)\end{array}$ & $\begin{array}{l}2.29 \\
(1.211)\end{array}$ \\
\hline N/A & 37 & 40 & $\begin{array}{l}1.86 \\
(1.492)\end{array}$ & $\begin{array}{l}1.64 \\
(1.436)\end{array}$ \\
\hline $\mathrm{C}$ & 38 & 37 & $\begin{array}{l}1.85 \\
(1.360)\end{array}$ & $\begin{array}{l}1.72 \\
(1.381)\end{array}$ \\
\hline $\mathrm{C}$ & 39 & 41 & $\begin{array}{l}1.84 \\
(1.182)\end{array}$ & $\begin{array}{l}1.63 \\
(1.150)\end{array}$ \\
\hline $\mathrm{C}$ & 40 & 39 & $\begin{array}{l}1.72 \\
(1.200)\end{array}$ & $\begin{array}{l}1.64 \\
(1.193)\end{array}$ \\
\hline N/A & 41 & 42 & $\begin{array}{l}1.58 \\
(1.301)\end{array}$ & $\begin{array}{l}1.55 \\
(1.286)\end{array}$ \\
\hline N/A & 42 & 43 & $\begin{array}{l}1.55 \\
(1.156)\end{array}$ & $\begin{array}{l}1.54 \\
(1.156)\end{array}$ \\
\hline $\mathrm{H}$ & 43 & 44 & $\begin{array}{l}1.52 \\
(1.200)\end{array}$ & $\begin{array}{l}1.51 \\
(1.193)\end{array}$ \\
\hline N/A & 44 & 46 & $\begin{array}{l}1.49 \\
(1.129)\end{array}$ & $\begin{array}{l}1.14 \\
(.916)\end{array}$ \\
\hline $\mathrm{H}$ & 45 & 38 & $\begin{array}{l}1.47 \\
(1.219)\end{array}$ & $\begin{array}{l}1.72 \\
(1.358)\end{array}$ \\
\hline $\mathrm{C}$ & 46 & 50 & $\begin{array}{l}1.38 \\
(1.248)\end{array}$ & $\begin{array}{l}1.05 \\
(1.095)\end{array}$ \\
\hline $\mathrm{H}$ & 47 & 45 & $\begin{array}{l}1.33 \\
(1.087)\end{array}$ & $\begin{array}{l}1.28 \\
(1.126)\end{array}$ \\
\hline $\mathrm{C}$ & 48 & 47 & $\begin{array}{l}1.25 \\
(1.049)\end{array}$ & $\begin{array}{l}1.14 \\
(1.049)\end{array}$ \\
\hline N/A & 49 & 48 & $\begin{array}{l}1.20 \\
(1.181)\end{array}$ & $\begin{array}{l}1.12 \\
(.988)\end{array}$ \\
\hline $\mathrm{C}$ & 50 & 49 & $\begin{array}{l}1.19 \\
(1.133)\end{array}$ & $\begin{array}{l}1.12 \\
(1.100)\end{array}$ \\
\hline N/A & 51 & 51 & $\begin{array}{l}.92 \\
(1.059)\end{array}$ & $\begin{array}{l}1.03 \\
(1.180)\end{array}$ \\
\hline
\end{tabular}




\begin{tabular}{|c|c|c|c|c|c|}
\hline 19 S. Some students show little desire to learn & $\mathrm{C}$ & 52 & 53 & $\begin{array}{l}.82 \\
(1.170)\end{array}$ & $\begin{array}{l}.67 \\
(1.097)\end{array}$ \\
\hline $\begin{array}{l}2 \mathrm{~S} \text {. Many of the students in my class try to get away with doing as } \\
\text { little work as possible }\end{array}$ & $\mathrm{C}$ & 53 & 55 & $\begin{array}{l}.68 \\
(1.805)\end{array}$ & $\begin{array}{l}.60 \\
(.968)\end{array}$ \\
\hline $6 \mathrm{~T}$. Using hand signals & N/A & 54 & 54 & $\begin{array}{l}.68 \\
(.854)\end{array}$ & .61 \\
\hline $8 \mathrm{~S}$. Students seldom take care of materials if not supervised & $\mathrm{C}$ & 55 & 56 & $\begin{array}{l}.65 \\
(.893)\end{array}$ & $\begin{array}{l}.45 \\
(.787)\end{array}$ \\
\hline $\begin{array}{l}20 \mathrm{~S} \text {. Students are more motivated by grades than the acquisition of } \\
\text { competence }\end{array}$ & $\mathrm{C}$ & 56 & 52 & $\begin{array}{l}.58 \\
(.925)\end{array}$ & $\begin{array}{l}.97 \\
(1.165)\end{array}$ \\
\hline 16 C. Students learn best in primarily teacher-directed classrooms & $\mathrm{C}$ & 57 & 57 & $\begin{array}{l}.49 \\
(.810)\end{array}$ & $\begin{array}{l}.43 \\
(.846)\end{array}$ \\
\hline $\begin{array}{l}12 \mathrm{~T} \text {. Using drill and recitation for factual information (math facts, } \\
\text { etc.) }\end{array}$ & $\mathrm{C}$ & 58 & 59 & $\begin{array}{l}.35 \\
(.809)\end{array}$ & .32 \\
\hline 7 C. Peer interactions are best left to recess and snack time & $\mathrm{C}$ & 59 & 58 & $\begin{array}{l}.34 \\
(.694)\end{array}$ & $\begin{array}{l}.35 \\
(.782)\end{array}$ \\
\hline $15 \mathrm{~T}$. Using worksheets & $\mathrm{C}$ & 60 & 60 & $\begin{array}{l}.34 \\
(.709)\end{array}$ & .25 \\
\hline
\end{tabular}

Description: Table 1 shows each statement card (i.e. belief); whether each statement/belief reflects a humanistic $(\mathrm{H})$ orientation, custodial (C) orientation (or not applicable [N/A]); the mean prioritization time one (before student teaching); the mean prioritization time two; the standard deviation (below each mean [in parentheses]); and the rank for each statement.

Other beliefs were highly prioritized prior to participating in student teaching. These included a focus on cognitive processes not products, student-directed active learning, fostering students' ability to self-regulate, modeling the behaviors they wish for students to emulate, and the discussion/posting of classroom rules as a means for maintaining clear expectations for student behavior.

Also embedded within the highest prioritizations were statements that could be operationalized as the fundamentals of effective classroom management and pedagogy. Examples include, "A classroom runs smoothly when there are clear expectations for behavior"; "Students learn best by being actively involved in lessons"; "Classroom rules should be discussed and posted"; "Students need to be met where they are in terms of their ability"; "Students learn best when they have good role models for behavior"; and the salience of "Modeling behavior for students" (Table 1).

\subsubsection{Least Prioritized Beliefs Prior to Student Teaching}

The least prioritized statements, from a ranking of 51 out of 60 to 60 out of 60 , reflect a custodial orientation: a lack of trust in students, teacher-directed instruction, and the use of worksheets, drills and traditional pedagogical practices. Also receiving a low rank was the belief that the allocation of extrinsic rewards would diminish student motivation (Table 1). The statement: "Students are more motivated by grades than the acquisition of competence," increased in relative priority. This belief, ranked 56 out of 60 at pre-internship, rose to a rank of 52 out of 60 at post- internship (Table 1). The increase in prioritization of the said statement is likely to reflect what pre-service teachers experienced while working in the field.

\subsubsection{Beliefs Prioritized in the Mid-Range Prior to Student Teaching}

Statements emblematic of a humanistic orientation are highly ranked within this middle division. For example, "Students need to be met where they are in terms of their ability," and "Permitting students to choose from a variety of activities," were ranked $20^{\text {th }}$ and $28^{\text {th }}$ pre-internship, respectively, and reflect a focus on student-directed learning. The statements, "Welcoming each student by name to class" and "Almost all children in my class try their best," ranked $25^{\text {th }}$ and $26^{\text {th }}$ respectively, are consistent with a humanistic belief orientation. Importantly, consistency in policies and procedures was also ranked highly. This constellation of beliefs is progressive, humanistic, and focused on the establishment of procedures and rules that are routinized, yet not in a custodial, top-down manner.

\subsection{Post Student-Teaching Beliefs}

\subsubsection{Consistently Prioritized Beliefs, After Having Student Taught}

The pre-service sample was once again asked to complete the TBQ within a month after completing their student teaching experience. Analyses reveal that several statements reflecting a humanistic orientation were still ranked highly, revealing a marked stability in belief orientations. For example, the statement "Students should feel as though they are 'known' and 'recognized' in the classroom" was ranked second in importance pre-internship and fourth in importance post-internship; "Students need to feel safe and secure in the classroom" was ranked fourth in importance pre-internship and rose to third in importance post-internship; and, "Students meet challenges best when they feel their teachers care about them" was ranked fifteenth in importance pre-internship and rose to eleventh in importance post-internship. 


\subsubsection{Beliefs Less or More Highly Prioritized After Having Student Taught}

Less highly prioritized by those who student taught was "If I treat students with respect, kindness and concern, there are less [sic] behavior problems" moving from a rank of nine pre-internship to a rank of sixteen post-internship.

Additionally, ranked eighth out of sixty statements pre-internship, "Self-monitoring (or self-regulation) are important skills for students to develop," dropped in prioritization to a rank of 18 post-internship (Table 1). "A classroom runs smoothly when there are clear expectations for behavior," increased in prioritization to be the highest ranking statement. In combination, these findings suggest the retention of a humanistic orientation with an increased emphasis the importance of providing students with clear, consistent expectations (Table 1).

In addition, more highly prioritized by those who student taught was "Students need some choice of activities in the classroom," moving from a rank of 27 pre-internship to a relatively high rank of 19 post-internship. Other statement cards that increased in prioritization from pre-internship to post-internship include: "A noisy classroom is okay as long as all the students are being productive"; "Praise from me is an effective way to change students' behavior"; "Students need opportunities to think in a quiet classroom environment"; "Working on group projects"; and, "The curriculum and class schedule need to be prioritized over specific student interests."

Thus, specific beliefs were prioritized differently after participants' completed their student teaching, presumably as a function of what they learned while teaching in the real world. These differences include an increased valuation of accepting classroom noise provided students are being productive, as well as the efficacy of using praise to shape student behavior. These changes also reflect a strengthened belief in student-directed learning as well as the efficacy of using extrinsic reinforcements to incentivize positive student behaviors and an understanding that a little student noise is tolerable provided they are working and "on-task."

\subsection{Increases and Decreases in Prioritization for Beliefs That Were Midrange}

Numbers of students shifting priority level was also evident for the group of statements near the midrange of mean priority at time one. Statements that were more frequently characterized as high priority time two in comparison to time one include: "Having a morning routine"; "Each of my students teaches me something"; "A noisy classroom is okay as long as all the students are being productive;" and "Praise from me is an effective way to maintain control."

Statements that were more frequently characterized as low priority time two in comparison to time one include "Talking about our plan or schedule for the day"; "Using a theme-based approach to instruction"; "The primary goal in dealing with students is to establish and maintain control"; and "Most students respect teachers and authority"; and "It is important to respect students' autonomy and expect them to behave in a responsible manner." Statements that were more frequently characterized as neutral in priority time two in comparison to time one include, "Welcoming each student by name to class," and "Proper control of a class is apparent when students work productively when I am out of the room."

\section{Discussion}

This study aimed to assess pre-service teachers' belief with respect to students, classroom management, and best pedagogical practices before and after their student teaching experience, as well as the degree to which such beliefs reflect a custodial versus humanistic orientation. Results from this study indicated that the statements participants' lowest and highest prioritizations reveal values in favor of active learning; a humanistic teaching style; a valuation of pedagogical practices espoused by information-processing theorists, such as a focus on thinking processes irrespective of products; and a general optimism about students, such as their willingness to work if adequately challenged. Also deemed to be a powerful learning tool was modeling, consistent with research on social cognition (Bandura, Ross, \& Ross, 1961). Least prioritized were teacher-led classrooms; contexts where student-to-student collegiality was constrained to "free periods"; the use of workbook pages and drills as pedagogical tools; and negative views of learners such as, "Some show a minimal interest in learning" or "Many cannot be expected to protect materials if left unsupervised."

Change in mean responses between pre- student teaching internship and post- student teaching internship pertain to student self-regulation and the administration of extrinsic rewards. The first, "Students are more motivated by grades [an extrinsic reward] than the acquisition of competence [an intrinsic reward]," was not highly prioritized before or after student teaching. However, it was a significantly stronger belief post- student teaching internship in comparison to prestudent teaching internship. Consistent with this was a second, significantly stronger belief in the value of allocating extrinsic rewards as a way to manage the classroom: "Praise from me is an effective way to change student behavior." If after having student taught, participants' believe the use of operant conditioning is a way to increase students' motivation to achieve and behave well in class then it is likely that a belief in students' capacity to self-regulate is diminished as well. This was the case, as the statement "Self-monitoring or self- regulation are important skills for students to develop" was significantly less highly prioritized on behalf of pre-service teachers after their student teaching internship. Thus, the 
notion that students will "do the right thing" based on their intrinsic desire to do so was attenuated and replaced with a stronger sense that they will perform well when given incentives to do so.

The smaller reliance on students to do "the right thing," possibly necessitated the presentation of explicit expectations on a regular basis. Consistent with this is a lowered prioritization of the statements, "If I treat students with respect, kindness, and concern, there are less behavior problems," and "Students should feel as though they are 'known' and 'recognized' in the classroom." Again, attending to students' affective needs may have been a less effective or more peripheral classroom management practice in comparison to making behavioral expectations explicit.

\subsection{Limitations of the Study}

One limitation of this study warrants discussion: the content validity for each statement card labeled as "custodial," "humanistic," or " $\mathrm{n} / \mathrm{a}$ " was not discerned; rather each card was assessed on its face validity. Thus, it is unclear whether several, individual observers trained in the field of education and well-versed in custodial, humanistic and other orientations would reliably categorize each statement similarly, verifying the content validity of each.

Despite this limitation, results of this study suggest that research using forced choice response measures such as the TBQ should be conducted in order to discern whether the beliefs espoused on behalf of cooperating teachers are related to orientations espoused by student teachers upon completion of their student teaching internships. In addition, studies using a q-sort are needed to track several teachers' beliefs longitudinally as a means for discerning stability and change over time. Concurrently assessing the contextual variables that may be related to these findings would be important to pursue. If beliefs in relation to classroom management, students, and pedagogical practices change among many second and third year teachers in accord with school norms and additional contextual variables, it may be prudent for teacher education programs to begin student teaching internships earlier in their training programs so that "real world" challenges can be reconciled with theories of best practice.

\section{References}

Abu-Jaber, M., Al-Shawareb, A., \& Gheith, E. (2010). Kindergarten teachers' beliefs toward developmentally appropriate practice in Jordan. Early Childhood Education, 38, 65-74. http://dx.doi.org/10.1007/s10643-010-0379-z

Anderson, L. M., \& Holt-Reynolds, D. (1995). Prospective teachers' beliefs and teacher education pedagogy: Research based on a teacher educator's practical theory. Unpublished manuscript. East Lansing: Michigan State University, National Center for Research on Teacher Learning.

Angelo, T. A., \& Cross, P. K. (1993). Classroom Assessment Techniques: A Handbook for College Teachers. (2nd ed.).

San Francisco: Jossey-Bass.

Albert, B., Dorothea, R., \& Sheila, R. A. (1961). Transmission of aggression thorough imitation of aggressive models. Journal of Abnormal and Social Psychology, 63, 575-582. http://dx.doi.org/10.1037/h0045925

Bagher, S. M. (2013). EFL learner's beliefs about language learning in Iran. International Journal of Language Learning and Applied Linguistics World, 4(4), 88-101.

Ball, D. L. (1990). The mathematical understandings that prospective teachers bring to teacher education. The Elementary School Journal, 90(4), 449-466.Ball, D.L. (2000). Bridging practices: Intertwining content and pedagogy in teaching and learning to teach. Journal of Teacher Education, 51(3), 241-247. http://dx.doi.org/10.1086/461626

Bandura, A., Ross, D., \& Ross, S. A. (1961). Transmission of aggression through imitation of aggressive models. Journal of Abnormal and Social Psychology, 63, 575-582. http://dx.doi.org/10.1037/h0045925

Blumenfeld, P., Soloway, E., Marx, R., Krajcik, J., Guzdial, M., \& Palincsar, A. (1991) Motivating project-based learning: Sustaining the doing, supporting the learning. Educational Psychologist, 26 (3 \& 4), 369-398. http://dx.doi.org/10.1080/00461520.1991.9653139

Borg, M. (2001). Key concepts in ELT: Teachers' beliefs. ELT Journal, 55(2), 186-187. http://dx.doi.org/10.1093/elt/55.2.186

Brimfield, R., \& Leonard, R. (1983). The student teaching experience: a time to consolidate ones perceptions. College Student Journal, 17, 40-406.

Buehl, M. M., \& Fives, H. (2009). Exploring teachers' beliefs about teaching knowledge: Where does it come from? Does it change? The Journal of Experimental Education, 77(4), 367-408. http://dx.doi.org/10.3200/JEXE.77.4.367-408

Calderhead, J., \& Robson, M. (1991). Images of teaching: Student teachers' early conceptions of classroom practice. 
Teaching and Teacher Education 7(1), 1-8. http://dx.doi.org/10.1016/0742-051X(91)90053-R

Capraro, M. M., Capraro, R. M., \& Helfeldt, J. (2010). Do different types of field experiences make a difference in teacher candidates' perceived level of competence? Teacher Education Quarterly, 37, 131-154.

Cassidy, C., Buell, M., Pugh-Hoese, S., \& Russell, S. (1995). The effect of education in child care providers' beliefs and classroom quality: Year one evaluation of the T.E.A.C.H. early childhood associate degree scholarship program. Early Childhood Research Quarterly, 10, 171-184. http://dx.doi.org/10.1016/0885-2006(95)90002-0

Charlesworth, R., Hart, C., Burts, D., \& Hernandez, S. (1991). Kindergarten teachers' beliefs and practices. Early Development and Care, 70, 17-15. http://dx.doi.org/10.1080/0300443910700103

Conant, J. (1963). The education of American teachers. New York: McGraw Hill.

Council for the Accreditation of Educator Preparation (2013). Washington, DC: Standards. http://caepnet.org/standards/standards/standard2/

Darling-Hammond, L., \& Baratz-Snowden, J. (Eds.). (2005). A good teacher in every classroom: Preparing the highly qualified teachers our children deserve, 38-39. San Francisco, CA: Jossey-Bass.

Doolittle S. A., Dodds, P., \& Placek, J. H. (1993). Persistence of beliefs about teaching during formal training of pre-service teachers. Journal of Teaching in Physical Education, 12, 355-365.

Edwards-Groves, C. J. (2014). Learning teaching practices: The role of critical mentoring conversations in teacher education. Journal of Education and Training Studies, 2(2). http://dx.doi.org/10.11114/jets.v2i2.343

Eisenhardt, S., Besnoy, K., \& Steele, E. (2012). Creating Dissonance in Pre-Service Teachers' Field Experiences`. Southeastern Regional Association of Teacher Educators, 21(1), 1-10.

Erdogan, N. I. (2015). A critical role of the student teaching on instructional beliefs: An example of early childhood student and cooperating teachers. Athens Journal of Education, 2(1), 53-64.

Ertmer, P. A. (2005). Teacher pedagogical beliefs: The final frontier in our quest for technology integration? Educational Technology Research and Development, 53(4), 25-39. http://dx.doi.org/10.1007/BF02504683

Fang, Z. (1996). A review of research on teacher beliefs and practices. Educational Research, 38(1), 47-65. http://dx.doi.org/10.1080/0013188960380104

File, N., \& Gullo, D. F. (2002). A comparison of early childhood and elementary education students' beliefs about primary classroom teaching practices. Early Childhood Research Quarterly, 17, 126-237. http://dx.doi.org/10.1016/S0885-2006(02)00130-8

Glickman, C., \& Tamashiro, R., (1982). A comparison of first-year, fifth-year, and former teachers on efficacy, ego development, and problem solving. Psychology in Schools, 19, 558-562. http://dx.doi.org/10.1002/1520-6807(198210)19:4<558::AID-PITS2310190426>3.0.CO;2-F

Grasha, A. F., \& Riechmann, S. (1996). Teaching Style Survey. Retrieved from: http://longleaf.net/teachingstyle.html Grossman, P. (2010). Learning to practice: The design of clinical experience in teacher preparation. Washington, D.C.: American Association of Colleges for Teacher Education.

Haymore, S. J. (2011). Pre-service teachers' conceptions of effective and ineffective teaching practices. Teacher Education Quarterly, Summer, 27-47.

Holmes Group. (1995). Tomorrow's schools of education: A report of the Holmes Group. East Lansing, MI: Author. Hoy, W. K. (1967). Organizational socialization: The student teacher and pupil control ideology. The Journal of Educational Research, 61(4), 153-155.

Hoy, W. K. (1968). The influence of experience on the beginning teacher. The School Review, 312-322. http://dx.doi.org/10.1086/442847

Hoy, W. K., \& Woolfolk, A. E. (1990). Socialization of student teachers. American Educational Research Journal, 27(2), 279-300. http://dx.doi.org/10.3102/00028312027002279

Johnson, J. S. (1982). What to do when the student teacher arrives. Kappa Delta Pi Record, 18(4), 98-104. Kagan, D. M. (1992). Implications of research on teacher belief. Educational Psychologist, 27(1), 65-90. http://dx.doi.org/10.1080/00228958.1982.10517688

Karavas, E., \& Drossou, M. (2010). How amenable are student teacher beliefs to change? A study of EFL student teacher beliefs before and after teaching practice. In A. Psaltou-Joycey \& M. Matheoudakis (Eds.), Advances in research on language acquisition and teaching: Selected papers (pp. 261-276). Greek Applied Linguistic Association, 
Thessaloniki.

King, K., Shumow, L., \& Lietz, S. (2001). Science education in an urban elementary school: Case studies of teacher beliefs and classroom practices. Science Education in an Urban Elementary School, 90-110. http://dx.doi.org/10.1002/1098-237x(200103)85:2<89::aid-sce10>3.0.co;2-h

La Paro, K. M., Siepak, K., \& Scott-Little, K. (2009) Assessing beliefs of preservice early childhood education teachers using Q-sort methodology. Journal of Early Childhood Teacher Education, 30(1), 22-36. http://dx.doi.org/10.1080/10901020802667805

Lin, H., Hazareesingh, N., Taylor, J., Gorrell, J., \& Carlson, H. (2001). Early childhood and elementary preservice teachers' beliefs. Journal of Early Childhood Teacher Education, 22(3), 135-150. http://dx.doi.org/10.1080/1090102010220302

Lombaerts, K., De Backer, F., Engels, N., van Braak, J., \& Athanasou, J. (2009). Development of the Self-Regulating Teacher Belief Scale. European Journal of Psychology of Education, 24(1), $79-96$. http://dx.doi.org/10.1007/BF03173476

Lortie, D. C. (1975). Schoolteacher: A Sociological Study. The University of Chicago Press: Chicago, Illinois.

Mayer, R. H. (2006). Learning how to teach young people how to think historically: A case study of one student teacher's experience. The Social Studies, March/April, 71-76. http://dx.doi.org/10.3200/tsss.97.2.69-76

McCombs, B. L., \& Whisler, L. S. (1997). The Learner Centered Classroom and School: Strategies for Increasing Student Motivation and Achievement. Jossey-Bass: San Francisco, CA.

Mischo, C., \& Maaß, K. (2013). The effect of teacher beliefs on student competence in mathematical modeling - an intervention study. Journal of Education and Training Studies, 1(1), 19-38. http://dx.doi.org/10.11114/jets.v1i1.24

Moore, B. D., \& Leonard, R. (1990). Consolidating perceptions of middle school teaching through participatory type early field experiences. Education, 111(1), 1-8.

Nespor, J. (1987). The role of beliefs in the practice of teaching. Journal of Curriculum Studies, 19, $317-328$. http://dx.doi.org/10.1080/0022027870190403

Nettle, E. B. (1998). Stability and change in the beliefs of student teachers during practice teaching. Teaching and Teacher Education, 14(2), 193-204. http://dx.doi.org/10.1016/S0742-051X(97)00031-0

Nilssen, V., \& Solheim, R. (2015). 'I see what I see from the theory I have read.' Student teachers learning through theory in practice. Journal of Education for Teaching: International research and pedagogy, http://dx.doi.org/10.1080/02607476.2015.1080423

Oh, D. M., Ankers, A. M., Llamas, J., \& Tomyoy, C. (2005). Impact of pre-service student teaching experience on urban school teachers. Journal of Instructional Psychology, 32(1), p 82-98.

Pajares, M. F. (1992). Teachers' beliefs and educational research: Cleaning up a messy construct. Review of Educational Research, 62(3), 307-332. http://dx.doi.org/10.3102/00346543062003307

Parker, A., \& Brindley, R. (2008). Exploring graduate elementary education pre-service teachers' initial teaching beliefs. The Professional Educator, 32(2), 1-41.

Raths, J. (2000).Teachers' beliefs and teaching beliefs. Early Childhood Research \& Practice, 385-391.

Richardson, V. (1996). The role of attitudes and beliefs in learning to teach. In J. Sikula (Ed.), The handbook of research in teacher education (2nd ed., pp. 102-119). New York: Macmillan.

Rimm-Kaufman, S. E., Storm, M., Sawyer, B., Pianta, R. C., \& La Paro, K. M. (2006). The Teacher Belief Q- Sort: A measure of teachers' priorities and beliefs in relation to disciplinary practices, teaching practices, and beliefs about children. Journal of School Psychology, 44 (2), 141-165. http://dx.doi.org/10.1016/j.jsp.2006.01.003

Rozelle, J., \& Wilson, S. (2012). Opening the black box of field experiences: How cooperating teachers' beliefs and practices shape student teachers' beliefs and practices. Teaching and Teacher Education, 28 (8), 1196-1205. http://dx.doi.org/10.1016/j.tate.2012.07.008

Sanderson, D. R. (2003). Maximizing the student teaching experience: Cooperating teachers share strategies for success. USCA Essays, 7, 1-14.

Smith, K. E. (1997). Student teachers' beliefs about developmentally appropriate practice: pattern, stability, and the influence of locus of control. Early Childhood Research Quarterly, 12(2), 221-243. http://dx.doi.org/10.1016/S0885-2006(97)90015-6 
Solomon, D., \& Battistich, V. (1996). Teacher beliefs and practices in schools serving communities that differ in socioeconomic level. Journal of Experimental Education, 64(4), 327-348. http://dx.doi.org/10.1080/00220973.1996.10806602

Spooner, M., Flowers, C., Lambert, R., \& Algozzine, B. (2008). Is more really better? Examining perceived benefits of an extended student teaching experience. Clearing House, 81(6), 263-270. http://dx.doi.org/10.3200/TCHS.81.6.263-270

Stipek, D. J., Givvin, K. B., Salmon, J. M., \& MacGyvers, V. (2001). Teachers' beliefs and practices related to mathematics instruction. Teaching and Teacher Education, 17, 213-226. http://dx.doi.org/10.1016/S0742-051X(00)00052-4

Tabachnick, B. R., \& Zeichner, K. (1984). The impact of the student teaching experience on the development of teacher perspectives. Journal of Teacher Education, 35, 28-36. http://dx.doi.org/10.1177/002248718403500608

Thomas, J. A., Pedersen, J. E., \& Finson, K. (2001). Validating the Draw-A-Science-Teacher-Test Checklist (DASTTC): Exploring mental models and teacher beliefs. Journal of Science Teacher Education, 12, 295-310. http://dx.doi.org/10.1023/A:1014216328867

The University of North Florida. (2014). University of North Florida Internship Handbook. Jacksonville, FL: Author.

Windschitl, M., \& Sahl, K. (2002). Tracing teachers' use of technology in a laptop computer school: The interplay of teacher beliefs, social dynamics, and institutional culture. American Educational Research Journal, 39(1), 165-205. http://dx.doi.org/10.3102/00028312039001165

Witcher, A. \& Travers, P. (1999). Witcher-Travers Survey of Educational Beliefs. http://www.abacon.com/witcher-travers

Woolley, S. L., Woolley, A. W., \& Hosey, M. (1999.) Impact of student teaching on student teachers' beliefs related to behaviorist and constructivist theories of learning. Paper presented at the meeting of the Association of Teacher Educators, Chicago.

Zeichner, K. M., \& Tabachnick, B. R. (1981). Are the effects of university education 'washed out' by school experience? Journal of Teacher Education, 32(3), 7-11. http://dx.doi.org/10.1177/002248718103200302

\section{Appendix. Web-based Teacher Belief Q-Sort}

\section{Statement Cards re: Beliefs about Classroom Management (C)}

1. "The primary goal in dealing with students' behavior is to establish and maintain control."

2. "A noisy classroom is okay as long as all the students are being productive."

3. "Students must be kept busy doing activities or they soon get into trouble."

4. "When students are engaged in interesting problems and challenging activities, they tend to have very few discipline problems."

5. "Proper control of a class is apparent when the students work productively while I am out of the room (either briefly or when only a substitute is present)."

6. "Monitoring students can prevent problematic situations."

7. "Peer interactions are best left to recess and snack time."

8. "The curriculum and class schedule need to be prioritized over students' specific interests."

9. "A classroom runs smoothly when there are clear expectations for behavior."

10. "Classroom rules should be discussed and posted."

11. "Self-monitoring (or self-regulation) are important skills for students to develop."

12. "It is important to respect students' autonomy and expect them to act in a responsible manner."

13. "Students should try to resolve conflicts on their own before going to the teacher."

14. "Rules for the students' classroom behavior need to be reinforced consistently."

15. "Praise from me is an effective way to change students' behavior."

16. "Students learn best in primarily teacher-directed classrooms."

17. "If I treat students with respect, kindness and concern, there are less behavior problems."

18. "Verbal punishment is an unacceptable means of controlling students' behavior; I believe it's more important to use only positive management techniques."

19. "If I anticipate problems before they happen and discuss them with the students, I have fewer discipline problems."

20. "Extrinsic rewards for desirable behavior (e.g., stickers, candy bars) undermine student's motivation; it's better not to give such rewards at all."

Statement Cards re: Beliefs about Teaching Practices (T)

1. "Having a morning routine." 
2. "Talking about our plan or schedule for the day."

3. "Welcoming each student by name to class."

4. "Doing an activity to create a sense of community."

5. "Talking about current events."

6. "Using hand signals."

7. "Having at least a few students share something that has happened to them."

8. "Discussing a written announcement or message created by the teacher."

9. "Conducting the business of the classroom (e.g., collecting lunch or milk money) following a set routine."

10. "Reflecting and talking about something such as a social interaction that 'worked' or 'didn't work' in our class."

11. "Reflecting on the content of an academic lesson and talking about what we learned."

12. "Using drill and recitation for factual information (math facts, etc.)."

13. "Modeling behaviors for students."

14. "Introducing new objects or new activities in the room through demonstration."

15. "Using worksheets."

16. "Permitting students to choose from a variety of activities."

17. "Encouraging students and giving feedback that focuses on the process of students' creations or thinking, not the outcomes or the solution."

18. "Using whole group instruction."

19. "Using a theme-based approach to instruction."

20. "Working on group projects."

Statement Cards re: Beliefs about Students $(S)$.

1. "Almost all children in my class try their best."

2. "Many of the students in my class try to get away with doing as little work as possible."

3. "Students should feel as though they are "known" and "recognized" in the classroom."

4. "Students need to be met where they are in terms of their ability."

5. "Each one of my students teaches me something."

6. "Almost all students are equally likable and enjoyable."

7. "Most students respect teachers and authority."

8. "Students seldom take care of their materials if they are not supervised."

9. "Students learn best when they have good role models for behavior."

10. "Students need some choice of activities within the classroom."

11. "Students need to work on skills at which they are not good, even if it means giving them fewer choices of activities."

12. "Students cannot be understood without knowing something about their families."

13. "Students meet challenges best when they feel that their teachers care about them."

14. "Students need to feel safe and secure in the classroom."

15. "Students need opportunities to think in a quiet classroom environment."

16. "Students need to have their strengths recognized to promote learning."

17. "Students learn best by being actively involved in lessons."

18. "Students need opportunities to be creative in the classroom."

19. "Some students show little desire to learn."

20. "Students are more motivated by grades than they are by the acquisition of competence." 